STRUCTURAL BRICKWORK 


\section{Structural Brickwork}

\section{Arnold W. Hendry}

B.Sc., Ph.D., D.Sc., F I.C.E.,

F. I.Struct.E., F.R.S.E.,

Professor of Civil Engineering, University of Edinburgh 
(C) Arnold W. Hendry 1981

Softcover reprint of the hardcover 1st edition 1981 978-0-333-25748-7

All rights reserved. No part of this publication may be reproduced or transmitted, in any form or by any means, without permission.

First published 1981 by

THE MACMILLAN PRESS LTD

London and Basingstoke

Associated companies in Delhi Dublin

Hong Kong Johannesburg Lagos Melbourne

New York Singapore and Tokyo

Typeset in 10/11 PR by

Reproduction Drawings Ltd, Sutton, Surrey

ISBN 978-1-349-81441-1 ISBN 978-1-349-81439-8 (eBook)

DOI 10.1007/978-1-349-81439-8 


\section{CONTENTS}

Preface

viii

1 Structural design of brickwork buildings 1

1.1 Introduction 1

1.2 Wall layout 2

1.3 Plain and reinforced brickwork 4

1.4 Limit state design of brickwork 4

$\begin{array}{ll}1.5 \text { Derivation of partial safety factors } & 6\end{array}$

$\begin{array}{ll}1.6 \text { Analysis of brickwork structures } & 6\end{array}$

2 The strength of brickwork 12

$\begin{array}{ll}2.1 \text { Compressive strength: general } & 12\end{array}$

$\begin{array}{ll}2.2 \text { Factors affecting compressive strength } & 13\end{array}$

2.3 Failure in compression: indications from standard tests 13

$\begin{array}{ll}2.4 \text { Interaction of brick and bed materials } & 13\end{array}$

$\begin{array}{ll}2.5 \text { Failure theories based on elastic analysis } & 15\end{array}$

2.6 Failure theories based on the strength of brick and mortar
under multi-axial stress

2.7 Empirical studies of the compressive strength of brickwork 26

$\begin{array}{ll}2.7 .1 \text { Brick characteristics } & 29\end{array}$

2.7.2 Effect of brickwork bond and wall type 31

2.7.3 Concentrated loads on brickwork $\quad 32$

$\begin{array}{ll}2.7 .4 \text { Chases in brickwork } & 33\end{array}$

2.8 The effect of workmanship factors on compressive strength $\quad 34$

2.8.1 Incorrect proportioning and mixing of mortar 35

2.8.2 Incorrect adjustment of suction rate 36

$\begin{array}{ll}2.8 .3 \text { Incorrect jointing procedures } & 40\end{array}$

2.8.4 Disturbance of bricks after laying $\quad 40$

2.8.5 Failure to build wall 'plumb and true to line and level'

2.8.6 Failure to protect work from the weather 41

2.8.7 Overall effects of workmanship on brickwork strength 43

2.9 The deformation properties of brickwork in compression 45

2.10 The strength and deformation of brickwork in shear
2.11 The strength of brickwork in tension 
3 The strength of brick masonry compression elements

3.1 Factors affecting the compressive strength of walls and piers 62

3.2 Empirical studies of the strength of walls and piers 62

3.3 Theoretical studies of the strength of compression elements 65

3.3.1 Differential equation for brittle columns 67

3.3.2 Solutions assuming deflection and stress-strain curves $\quad 72$

3.4 Wall-floor slab interaction 72

3.4.1 Wall strength in terms of end rotation 74

3.4.2 Wall-floor slab joints $\quad 77$

3.5 Moment magnifier method 81

3.6 Special wall types 83

3.6.1 Cavity walls 83

3.6.2 Stiffened walls $\quad 85$

4 Design analysis of unreinforced brickwork structures 91

4.1 General 91

4.2 Vertical load analysis $\quad 91$

4.2.1 Load distribution on walls 91

4.2.2 Analytical models for vertical load analysis 93

4.2.3 Frame analysis applied to brickwork structures 93

4.2.4 Experimental verification of frame action in brickwork
structures

4.2.5 Approximate calculation of eccentricities $\quad 110$

4.3 Lateral load analysis $\quad 114$

4.3.1 Frame analysis for lateral loads 116

4.3.2 Benjamin's method for irregular wall arrays $\quad 116$

5 Laterally loaded unreinforced walls $\quad 122$

5.1 General 122

5.2 The strength of brickwork panels without precompression 122

5.2.1 Experimental studies $\quad 122$

5.2.2 Calculation of strength of laterally loaded panels $\quad 123$

5.3 Lateral strength of walls with precompression $\quad 126$

5.3.1 Experimental studies $\quad 126$

$\begin{array}{ll}5.3 .2 \text { Theoretical treatment } & 127\end{array}$

5.4 The lateral strength of infill panels 131

5.4.1 Arching theories for strip walls 131

5.4.2 Walls supported on four sides 137

$\begin{array}{ll}5.4 .3 \text { An approximate theory for infill panels } & 139\end{array}$

6 Reinforced and prestressed brickwork 144

6.1 The application of reinforced and prestressed brickwork 144

6.2 Reinforced brickwork flexural elements 144

6.2.1 Flexural strength of reinforced brickwork 146 
6.2.2 Shear strength of reinforced brickwork beams 149

6.2.3 Calculation of deflection of reinforced brickwork beams $\quad 154$

$\begin{array}{ll}6.3 \text { Reinforced brickwork compression elements } & 155\end{array}$

$\begin{array}{ll}6.4 \text { Reinforced brickwork shear walls } & 160\end{array}$

$\begin{array}{ll}\text { 6.5 Prestressed brickwork } & 160\end{array}$

7 The resistance of brickwork structures to accidental damage 165

$\begin{array}{ll}7.1 \text { Abnormal loading incidents } & 165\end{array}$

$\begin{array}{ll}7.2 \text { Direct design for accidental damage } & 166\end{array}$

$\begin{array}{ll}7.3 \text { Indirect design for accidental damage } & 169\end{array}$

$\begin{array}{ll}7.4 \text { Experimental studies of accidental damage } & 170\end{array}$

8 Brick masonry walls in composite action 176

$\begin{array}{ll}8.1 \text { Composite wall-beam elements } & 176\end{array}$

8.1.1 Structural action of wall-beams $\quad 176$

$\begin{array}{ll}\text { 8.1.2 Theoretical solutions } & 177\end{array}$

8.1.3 Experimental results and verification of wall-beam theories 186

$\begin{array}{ll}8.2 \text { Infilled frames } & 189\end{array}$

$\begin{array}{ll}\text { 8.2.1 Structural action of infill panels } & 189\end{array}$

8.2.2 Calculation of strength and stiffness of infilled frames $\quad 190$

$\begin{array}{ll}\text { 8.2.3 Infill panels with openings } & 197\end{array}$

$\begin{array}{lr}\text { Author Index } & 205\end{array}$

$\begin{array}{lr}\text { Subject Index } & 208\end{array}$ 


\section{PREFACE}

It is commonplace to observe that brick masonry is one of man's oldest building materials, but the design of brickwork building structures in accordance with modern structural engineering principles is quite new. It is true that isolated series of tests on walls and piers were carried out in various countries in the late nineteenth and early twentieth centuries but it was not until around the middle of the twentieth century that sufficient information was available to permit the preparation of codes of practice containing essential data on masonry strength and reduction factors for slenderness and eccentricity. The early codes provided a basis for the design of compression elements and were used on the structural design of many high-rise buildings from the late 1950s onwards.

The application of engineering principles, however, necessarily remained incomplete, as the theoretical basis for the design of masonry elements had not then been evolved and analytical procedures were rudimentary as compared to those applied to structural design in steel and concrete. The essential problem in masonry design is that of the compression element of brittle material. The theory of brittle columns having idealised end conditions was therefore the first to receive attention. A solution was in fact produced as early as 1937 but seems to have been largely overlooked and the main development of brittle column theory took place from the mid-1950s with new and modified solutions still being produced.

The practical application of these theories is limited by the difficulty of relating the assumed end conditions to the actual conditions in a building where the eccentricity of loading and the behaviour of the element are influenced by interaction between masonry walls and concrete floors. The codes of practice include empirical rules which permit the designer to arrive at a practically satisfactory result, but which have little established correlation with the real behaviour of structures. Research work on wall-floor slab interaction was undertaken in Scandinavia in the early 1960s and is reflected in the Swedish code which takes into account the position of a wall relative to the top of the building in relation to the capacity reduction factors for slenderness and eccentricity. This example has not yet been followed in other national codes but further research work has been carried out on the problem with a view to improving the rational foundation for the design of brick masonry walls and columns.

The interaction between walls and floor slabs is also of importance in relation to wind loading. This became of importance with the construction of high-rise 
buildings with slender walls for which accurate methods of lateral load analysis were required. The earliest methods omitted consideration of the bending moments in inter-connecting floors or beams and distributed the wind moment among the watls in proportion to their stiffness. This method was extended in the 1950 s to deal with torsional effects. Later, more refined methods, originally derived for reinforced concrete shear walls, were applied to brickwork structures and their validity was checked by large-scale tests on sections of brickwork construction.

While these analytical methods were being devèloped, a more complete understanding of the behaviour of brickwork under compressive and shear stresses was being promoted and, although still incomplete, has strengthened the purely empirical basis of the design codes.

Experience has shown that brickwork structures are remarkably resistant to accidental forces, such as gas explosion and vehicle impact, but during the late 1960s and early 1970s public concern developed as a result of a number of building failures from such causes. A considerable amount of research work was therefore carried out during this period to provide quantitative information on the resistance of brickwork structures and elements to accidental damage. This work has been carried out mainly in the United Kingdom, where the concern seems to have been greatest.

The strength of brick panels under lateral loading has also attracted a great deal of attention during the past decade. This has arisen from the requirement in a number of countries to justify the stability of such walls against prescribed wind loadings, which have been increased in recent years, and to arrive at wall thicknesses that would be economically acceptable and consistent with existing experience. This has proved to be a difficult task and although partially solved by extensive testing still awaits a comprehensive theoretical solution. Laterally loaded walls with precompression or with boundary restraint giving rise to in-plane forces have also been investigated. These are capable of resisting very much higher lateral pressures than the ron-loadbearing panels referred to above, and in this case theoretical treatment has proved easier to develop and is relevent to consideration of resistance of brickwork structures to explosive forces.

Reinforced brickwork has been used on occasions for a great many years especially in countries such as India and the United States, which have to contend with earthquakes. Research work on reinforced masonry beams was carried out early in the twentieth century, but only recently has interest in this form of construction emerged in Western Europe, giving rise to research programmes in this field. It is probable that economic factors will favour this development which is likely to extend to the application of prestressing techniques to brickwork elements.

The whole field of research in brickwork construction has developed remarkably since the mid-1960s, and has been reflected by the holding of regular conferences devoted to the subject since 1967. Many papers have also appeared in technical journals and in the proceedings of national symposia during the same period, so that a considerable literature exists on most of the problems outlined above. The object of this book is to review existing knowledge of the 
structural engineering aspects of brick masonry construction. It is hoped that this will be of service to structural engineers by enabling them to extend their knowledge of the subject beyond the limits of codes of practice, and that it will help to place the structural design of brick masonry on a scientific and technical basis comparable to that of steel and concrete.

I acknowledge my debt to the numerous authors whose work I have quoted. I am particularly indebted to my colleagues and research students in Edinburgh University who, over the years, have contributed greatly to our practical and theoretical knowledge of brickwork. Finally, I express my thanks to the brick industry in the United Kingdom for their support of my research work and to my many friends in the masonry world for their comradeship and for their encouragement in pursuing my studies of brickwork construction.

ARNOLD W. HENDRY 